\title{
Correction to: AIDS Patient Care and STDs 2018;32:306-313; DOI: 10.1089/apc.2018.0028
}

N THE ARTICle, "Early Retention in Care Neither Mediates Nor Modifies the Effect of Sex and Sexual Mode of HIV Acquisition on HIV Survival in the Americas," there was an error in the authorship listing. One of the authors was listed as Yanink Caro-Veja, but the correct spelling is Yanink Caro-Vega. The authorship listing should read as follows:

Lara Coelho, MD, PhD, Peter F. Rebeiro, PhD, MHS, Jessica L. Castilho, MD, MPH, Yanink Caro-Vega, Fernando A. Mejia, MD, Carina Cesar, MD, Claudia P. Cortes, MD, Denis Padgett, MD, Catherine C. McGowan, MD, Valdiléa G. Veloso, MD, PhD, Timothy R. Sterling, MD, Beatriz Grinsztejn, MD, PhD, Bryan E. Shepherd, PhD, and Paula M. Luz, MD, PhD; for the CCASAnet

The online version of the article has been corrected to reflect this change.

The authors regret this error. 